Committee on Applied Mathematics:

Walter Bartky (Chairman), R. V. Churchill, G. C. Evans, Richard Courant, John von Neumann, William Prager.

Committee on Known Results:

R. P. Boas (Chairman), Arthur Erdélyi, George Pólya, Antoni Zygmund.

Committee on Library and Housing:

T. H. Hildebrandt (Chairman), Arnold Dresden, B. P. Gill, J. R. Kline, Marston Morse, P. A. Smith.

Editorial Committee for Applied Mathematics Symposium Proceedings:

A. H. Taub (Chairman), Eric Reissner, J. J. Stoker.

Birkhoff Editorial Committee:

D. V. Widder (Chairman), C. R. Adams, R. E. Langer, Marston Morse, M. H. Stone.

Birkhoff Memorial Finance Committee:

Saunders MacLane (Chairman), R. C. Archibald, J. L. Coolidge, G. C. Evans, Marston Morse, G: B. Price, Hermann Weyl, J. W. T. Youngs.

Committee to prepare pamphlet to aid in reading Russian mathematical articles:

Samuel Eilenberg (Chairman), Lipman Bers, P. R. Halmos, G. Y. Rainich, A. E. Ross.

Committee on translation of Russian and other mathematical articles:

R. P. Boas (Chairman), Samuel Eilenberg, D. H. Lehmer, William Prager, G. Y. Rainich.

\title{
INTERNATIONAL CONGRESS OF MATHEMATICIANS
}

Cambridge, Mass., August 30-September 6, 1950

Organizing Committee:

Garrett Birkhoff (Chairman), W. T. Martin (Vice-Chairman), A. A. Albert, J. L. Doob, G. C. Evans, T. H. Hildebrandt, J. R. Kline, Solomon Lefschetz, Saunders MacLane, Marston Morse, R. G. D. Richardson, Oswald Veblen J. L. Walsh, Hassler Whitney, D. V. Widder, R. L. Wilder.

Editorial Committee:

Einar Hille, P. A. Smith, Oscar Zariski.

Financial Committee:

John von Neumann (Chairman), J. L. Coolidge, B. P. Gill, M. H. Ingraham, W. L. G. Williams.

Secretariat:

J. R. Kline (Secretary); R. P. Boas (Associate Secretary).

Permanent Subcommittees of the Organizing Committee Budget Committee:

B. P. Gill (Chairman), J. R. Kline, G. B. Price, Oswald Veblen, Oscar Zariski. 


\section{Cooperation Committee:}

Hassler Whitney (Chairman), E. F. Beckenbach, Samuel Eilenberg, S. S. Wilks, J. W. T. Youngs.

Entertainment Committee:

L. H. Loomis (Chairman), C. R. Adams, Mrs. L. V. Ahlfors, Mrs. G. D. Birkhoff, J. A. Clarkson, Mrs. W. C. Graustein, F. B. Hildebrand, J. R. Kline, E. R. Lorch, Mrs. W. T. Martin, E. B. Mode, G. A. O'Donnell, Mrs. H. B. Phillips, Helen G. Russell, J. H. Van Vleck, Mrs. J. L. Walsh, Mrs. D. V. Widder, Mrs. Norbert Wiener.

Publicity Committee:

G. W. Mackey (Chairman), A. A. Bennett, R. P. Boas, J. A. Clarkson, C. O. Oakley, R. M. Thrall.

\section{FORMER PRESIDENTS}

J. H. Van Amringe, 1889-1890.

Emory McClintock, 1891-1894.

G. W. Hill, 1895-1896.

Simon Newcomb, 1897-1898.

R. S. Woodward, 1899-1900.

E. H. Moore, 1901-1902.

T. S. Fiske, 1903-1904.

W. F. Osgood, 1905-1906.

H. S. White, 1907-1908.

Maxime Bôcher, 1909-1910.

H. B. Fine, 1911-1912.

E. B. Van Vleck, 1913-1914.

E. W. Brown, 1915-1916.

L. E. Dickson, 1917-1918.
Frank Morley, 1919-1920.

G. A. Bliss, 1921-1922.

Oswald Veblen, 1923-1924.

G. D. Birkhoff, 1925-1926.

Virgil Snyder, 1927-1928.

E. R. Hedrick, 1929-1930.

L. P. Eisenhart, 1931-1932.

A. B. Coble, 1933-1934.

Solomon Lefschetz, 1935-1936.

R. L. Moore, 1937-1938.

G. C. Evans, 1939-1940.

Marston Morse, 1941-1942.

M. H. Stone, 1943-1944.

T. H. Hildebrandt, 1945-1946.

\section{ENDOWMENT FUND}

In 1923 an Endowment Fund was collected to meet the greater demands on the Society's publication program caused by the ever increasing number of important mathematical memoirs. Of this fund, which now amounts to some $\$ 71,000$, a considerable proportion was contributed by members of the Society. Under the terms of the will of the late Robert Henderson, for many years a Trustee of the Society, the Society receives approximately $\$ 4,000$ yearly. Upon the death of the other legatees, the Society will receive the entire principal of the estate for its Endowment Fund.

\section{SPECIAL FUNDS}

\section{The Bôcher Memorial Prize.}

This prize was founded in memory of Professor Maxime Bôcher. It is awarded every five years for a notable research memoir in analysis which has appeared during the preceding five years in a recognized journal published in the United States or Canada; the recipient must be a member of the Society, and not more than fifty years old at the time of publication of his memoir. 